Article

\title{
Acoustic Emission Monitoring of High-Strength Concrete Columns Subjected to Compressive Axial Loading
}

\author{
Rami Eid $^{1, * \mathbb{D}}$, Boris Muravin ${ }^{2}$ and Konstantin Kovler ${ }^{3}$ \\ 1 Civil Engineering Department, SCE-Shamoon College of Engineering, Beer Sheva 8410802, Israel \\ 2 Integrity Diagnostics Ltd., Netanya 4250407, Israel; boris@ndt.co.il \\ 3 Faculty of Civil and Environmental Engineering, Technion-Israel Institute of Technology, \\ Haifa 3200003, Israel; cvrkost@technion.ac.il \\ * Correspondence: ramiei@sce.ac.il
}

Received: 19 June 2020; Accepted: 10 July 2020; Published: 13 July 2020

check for updates

\begin{abstract}
Acoustic Emission (AE) nondestructive tests have attracted great interest for their use in the determination of structural properties and behavior of reinforced concrete (RC) elements. One of the applications this method can contribute to is in high-strength concrete (HSC) columns. These elements have a great advantage in the lower stories of high-rise buildings. However, the premature failure of the concrete cover and the brittleness nature of the failure is of a concern for engineers. This paper presents a study on the AE monitoring of HSC columns subjected to compressive axial loading. The study consists of four large-scale reinforced HSC columns with different confinement reinforcement and height. It is shown that the AE distributions in the columns are categorized by three stages. Moreover, the levels of loads reached at the first AE macro event are similar to the lower range levels of the nominal axial compressive strengths of the tested specimens, while the majority of macro AE events are located at the concrete cover. Based on the results of this study, AE monitoring can provide indications for the damage and load levels attained by reinforced high-strength concrete columns subjected to compressive axial loading.
\end{abstract}

Keywords: reinforced-concrete; acoustic emission; AE; columns; high-strength concrete; HSC; transverse steel reinforcement; confinement

\section{Introduction}

The use of high-strength concrete (HSC) for the lower story columns in high-rise buildings is very attractive for architects and engineers [1]. One of the main concerns of using HSC for such critical structural elements is the brittleness nature of the failure mode. Confinement through transverse steel reinforcement (TSR) can transfer the failure mode to a more ductile one; however, the failure of the column's concrete cover cannot be prevented by the confinement. Spalling off the concrete cover occurs prematurely, i.e., before the concrete reaches its full compressive strength (derived from tests of standard cylinders- $150 \mathrm{~mm}$ diameter by $300 \mathrm{~mm}$ height) [2,3]. It should be noted that concrete spalling can result also from exposure to fire [4,5]. This phenomenon is dominant in HSC and one of the protection methods is the addition of polypropylene fibers to the concrete mixture. These fibers melt during the exposure to fire allowing the release of the steam pressure, thus reducing the risk of concrete spalling [6]. Nondestructive tests (NDT) methods based on acoustic, electromagnetic, thermographic, and optical phenomena are becoming more popular for determining several structural properties and behavior of reinforced concrete (RC) elements [7-9]. For example, thermographic testing can monitor the temperatures which can influence the reinforcement corrosion in concrete [8]. Electromagnetic NDT can be used to detect location and diameter of reinforcement bars in RC elements 
and fiber spacing in steel fiber-reinforced concrete elements $[9,10]$. Ultrasonic methods are used to detect concrete cracking due to steel reinforcement corrosion [11,12].

The Acoustic Emission (AE) nondestructive test method was used by several research studies to examine the failure mode and the development of cracks in structural RC elements [13,14]. Studies have investigated the use of AE technique on normal strength concrete (NSC) columns cast in stay-in-place fiber-reinforced polymer (FRP) tubes [15] or wrapped with FRP [16]. These studies showed that the cumulative AE counts can indicate the stage of damage [15] and provides a better understanding of the crack process of FRP-confined NSC columns [16]. Puri and Weiss [17] performed axial compressive loading and unloading tests on NSC cylinders ( $76 \mathrm{~mm}$ diameter by $406 \mathrm{~mm}$ height). They found a linear relationship between the AE energy and the dissipated fracture energy, and thus the AE energy can be used to evaluate the column's damage. Other studies $[18,19]$ found a high correlation between the AE-strain hysteretic energies of RC beam-column connections and slabs under simulated earthquake loadings. These studies proposed formulas based on the recorded $\mathrm{AE}$ to predict the damage level for the examined RC elements. Moreover, AE signals were used to analyze the damage of confined circular concrete-filled steel tubular (CCFT) columns [20] and FRP-CCFT columns and showed the possibility of $\mathrm{AE}$ to predict initial steel yielding and to provide failure warning [21]. The AE technique was also implemented for $\mathrm{RC}$ beams and revealed that $\mathrm{AE}$ parameters increased with increasing beam thickness [22]. The present study examines the damage levels of HSC-reinforced columns subjected to axial compressive loading. Moreover, the study aims to investigate the premature failure of HSC cover in RC circular columns. This premature failure is the main reason of the higher safety factors used in the design of reinforced HSC compared to NSC columns [1,23-25].

\section{Experimental Program}

An experimental program was designed and performed to investigate the effectiveness of the $\mathrm{AE}$ technique for monitoring the cracking development and the damage levels of HSC columns. The experimental program included four circular reinforced HSC column specimens of $250 \mathrm{~mm}$ diameter. The test variables are as follows. The height of the columns are $H=750$ and $1000 \mathrm{~mm}$, and the volumetric transverse reinforcement ratios are $\rho_{s}=0.44$ and $2.03 \%$. These variables were chosen in order to examine their influence on the damage levels and the cracking development monitored by the AE technique in HSC columns subjected to axial compressive loading. The specimens are defined by the TSR hoops bar diameter $(6$ and $12 \mathrm{~mm}$ ) and spacing $(120$ and $100 \mathrm{~mm})$ and by the height of the specimen ( $S$ for $H=750 \mathrm{~mm}$ and $L$ for $H=1000 \mathrm{~mm}$ ). Details of the specimens tested at the National Building Research Institute laboratory at the Technion-Israel Institute of Technology are presented in Table 1 and Figure 1.

Table 1. Details of reinforced concrete specimens.

\begin{tabular}{|c|c|c|c|c|c|c|c|c|c|c|}
\hline & \multirow[b]{2}{*}{$\begin{array}{c}\text { Specimen } \\
\text { No. }\end{array}$} & \multirow[b]{2}{*}{$\begin{array}{c}f_{c}^{\prime} \\
\mathbf{M P a}\end{array}$} & \multirow[b]{2}{*}{$\begin{array}{c}D \\
\mathrm{~mm}\end{array}$} & \multirow[b]{2}{*}{$\begin{array}{c}H \\
\mathbf{m m}\end{array}$} & \multicolumn{2}{|c|}{$\begin{array}{l}\text { Longitudinal } \\
\text { Reinforcement }\end{array}$} & \multicolumn{4}{|c|}{ Transverse Reinforcement } \\
\hline & & & & & $\begin{array}{c}f_{y} \\
\mathbf{M P a}\end{array}$ & $\begin{array}{c}\rho_{s \ell} \\
\%\end{array}$ & $\begin{array}{c}\phi_{h} \\
\mathrm{~mm}\end{array}$ & $\begin{array}{c}s \\
\mathrm{~mm}\end{array}$ & $\begin{array}{c}f_{y h} \\
\text { MPa }\end{array}$ & $\begin{array}{l}\rho_{s} \\
\%\end{array}$ \\
\hline 1 & F06S120S & 84.8 & 250 & 750 & 433 & 1.88 & 6 & 120 & 288 & 0.44 \\
\hline 2 & F06S120L & 72.1 & 250 & 1000 & 433 & 1.88 & 6 & 120 & 288 & 0.44 \\
\hline 3 & F12S100S & 75.9 & 250 & 750 & 433 & 1.88 & 12 & 100 & 435 & 2.03 \\
\hline 4 & F12S100L & 86.3 & 250 & 1000 & 433 & 1.88 & 12 & 100 & 435 & 2.03 \\
\hline
\end{tabular}



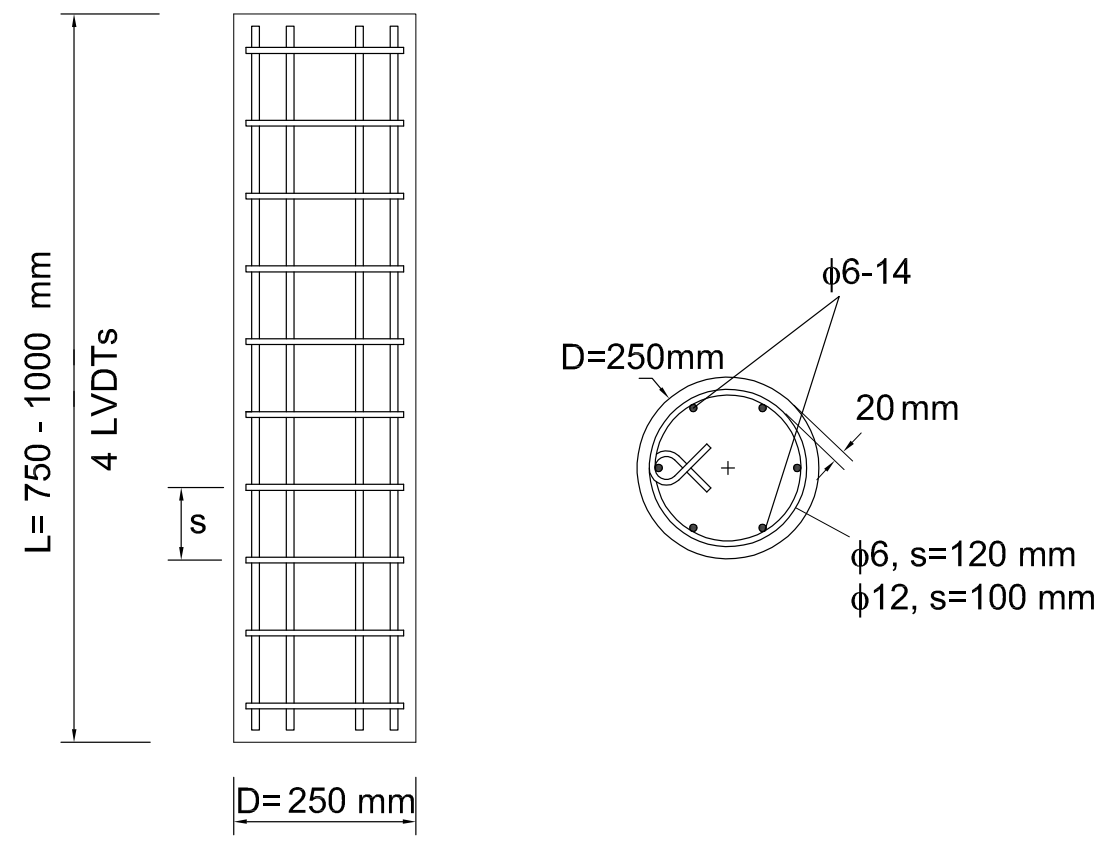

Figure 1. Reinforcement cage properties of tested columns.

\subsection{Material Properties}

\subsubsection{Concrete}

The target concrete unconfined strength of the designed specimens was set to $78 \mathrm{MPa}$. The concrete mixture of the specimens was prepared in the laboratory. The concrete mixture properties, which had a 0.27 water-cement ratio, are given in Table $2[1,26]$. It should be noted that the amount of polypropylene fibers used can be sufficient to minimize concrete spalling of HSC exposed to fire [4]. However, in this study, the intention of adding polypropylene fibers to the concrete mixture is to reduce the possible plastic shrinkage. Three standard concrete cylinders $150 \mathrm{~mm} \times 300 \mathrm{~mm}$ (diameter $\times$ height) were tested under axial compression to derive the concrete average compressive strength at 28 days (=testing time), $f_{c}^{\prime}($ Table 1$)$.

Table 2. Properties of concrete mixture.

\begin{tabular}{lc}
\hline Variable & $\mathbf{( k g / \mathbf { m } ^ { \mathbf { 3 } }}$ \\
\hline Cement & 460 \\
Fine aggregate-quartz sand & 220 \\
Intermediate aggregate $(9 \mathrm{~mm})$ & 900 \\
Coarse aggregate $(19 \mathrm{~mm})$ & 550 \\
High-Range Water Reducer & 9 \\
Fly Ash & 100 \\
Polypropylene Fibers & 1 \\
Water & 150 \\
\hline Slump (mm) & 175 \\
Water to cementitious materials w/cm & 0.27 \\
\hline
\end{tabular}

\subsubsection{Steel Reinforcement}

The longitudinal steel reinforcement consisted of six $14 \mathrm{~mm}$ diameter deformed bars. Hoops of $6 \mathrm{~mm}$ diameter plain bars and $12 \mathrm{~mm}$ deformed bars were used as TSR. At least three tensile tests were performed on reinforcement bar coupons for each batch of steel to obtain the average yield strength (Table 1). 


\subsection{Test Set-Up and Instrumentation}

The RC columns and the concrete cylinders were cured for 7 days and after that were laid in the laboratory ambient conditions to the day of testing. Specimen axial displacement was recorded using four Linear Variable Differential Transformers (LVDTs). Two LVDTs (with a gauge length of $500 \mathrm{~mm}$ for specimens F06S120S and F12S100S and $750 \mathrm{~mm}$ for specimens F06S120L and F12S100L) were attached to the steel collars installed at the top and bottom of the specimens to prevent local failure, and another two LVDTs were attached to the press's rigid steel plates (Figure 2). A load cell was used to measure the compressive load applied during the test. AE test method was applied to monitor initiation and development of damage in RC columns to failure. For this purpose, a multichannel acoustic emission system PCI8 manufactured by Mistras corporation was used. Monitoring was performed using nine $150 \mathrm{kHz}$ resonant sensors mounted using cyano-acrylic adhesive and placed as specified in Figures 1-3. The acoustic emission parameters of the detected and measured signals during the test included time of AE wave arrival, peak amplitude, energy, absolute energy, signal strength, rise time, duration, counts, average frequency, root mean square (RMS), and average signal level (ASL). Signal detection was performed using fixed threshold at all channels. For each detected signal, a corresponding waveform was recorded. Moreover, steel cups were used for sand capping the ends of the columns to ensure uniform distribution of the loading (Figure 2). The specimens were tested under compressive axial loading rate of $3 \mathrm{kN} / \mathrm{s}$. The rigid hydraulic press used for testing has load-controlled capabilities and a capacity of $5000 \mathrm{kN}$ (see Figure 2).

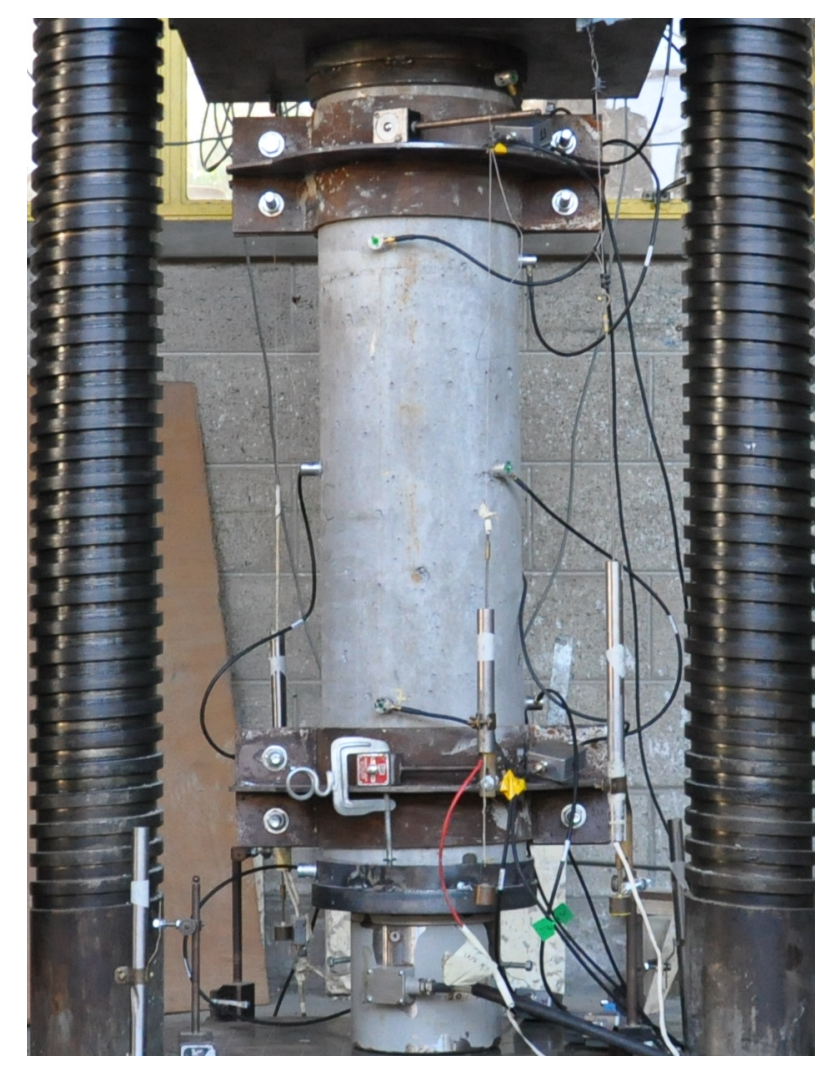

Figure 2. Test set-up of the reinforced concrete column specimens. 

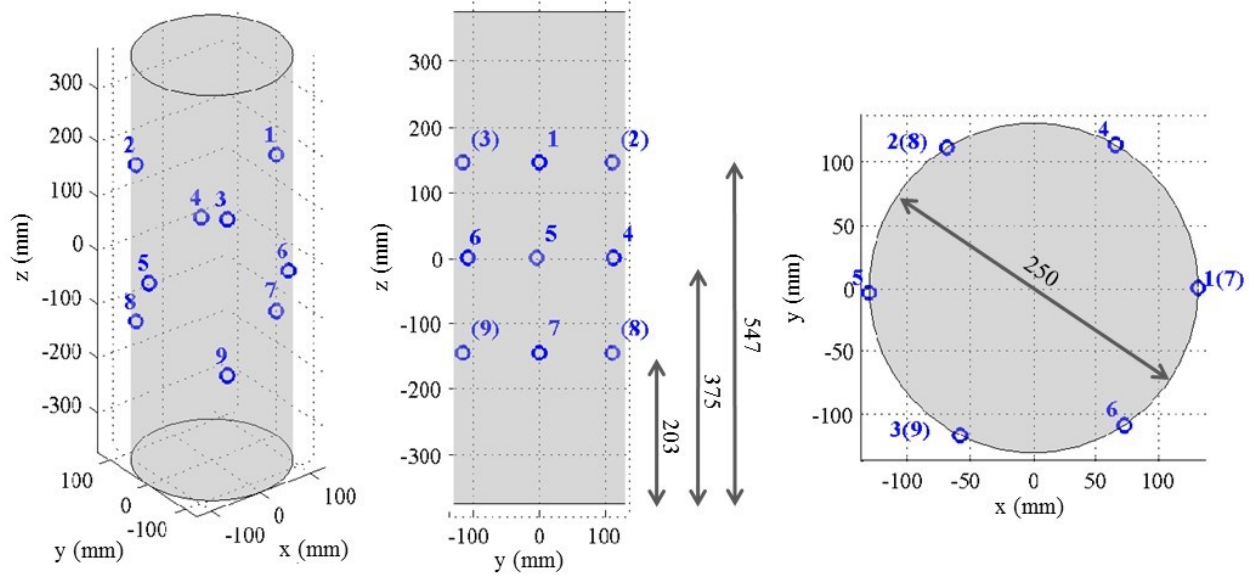

(a)
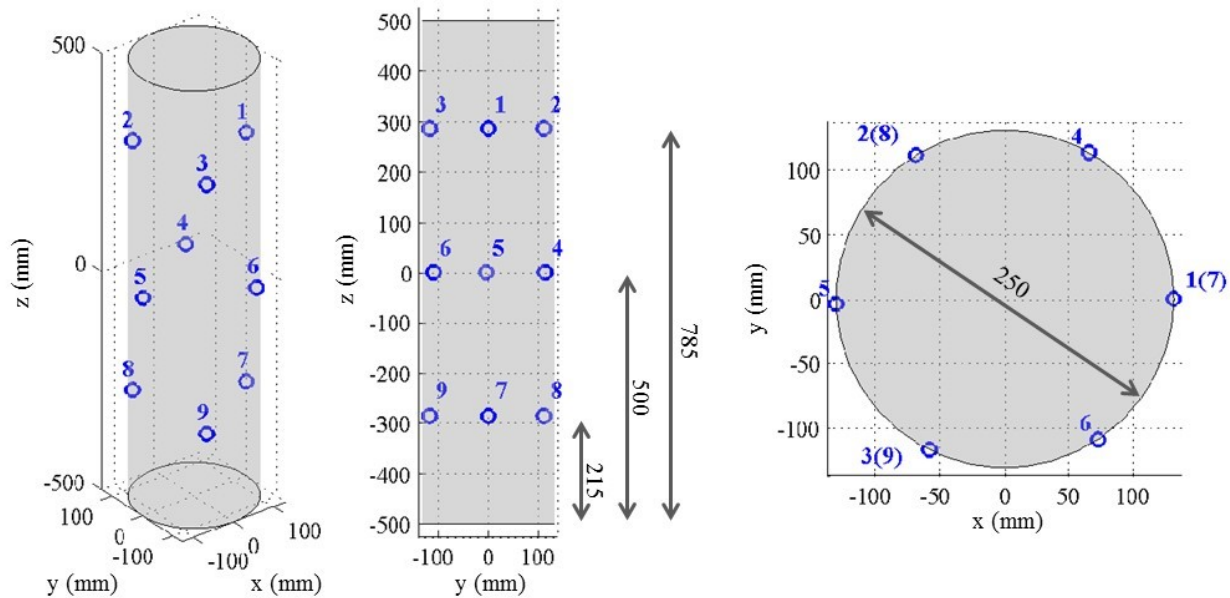

(b)

Figure 3. Position of Acoustic Emission (AE) sensors (a) specimens F6S120S and F12S100S, and (b) specimens F6S120L and F12S100L.

\section{Test Results}

\subsection{General}

Figure 4 shows the appearance of the columns after testing. Figure 5 show the axial compressive load versus the axial strain (measured from the central LVDT's) of the tested specimens. Moreover, Table 3 presents the maximum compressive axial load, $P_{\text {max }}$; its corresponding strain, $\epsilon_{c 1}$; the post-peak strain at $50 \%$ of the maximum load, $\epsilon_{c p 50}$; and the area under the load-strain curves, $A_{p 50}$. The latter two parameters indicate the level of ductility reached by the specimens. It is shown in Figure 5 and Table 3 that, as expected, the overall behavior of specimens F12S100S and F12S100L (with higher amounts of TSR) is better than that of specimens F06S120S and F06S120L in terms of axial load capacity and ductility. It should be noted that the axial strain in Figure 5 is calculated based on the LVDTs gauge lengths equal to $500 \mathrm{~mm}$ for the shorter specimens (F06S120S and F12S100S) and $750 \mathrm{~mm}$ for the longer specimens (F06S120L and F12S100L). As the local failure of the specimens with a similar amount of TSR (i.e., F06S120S-F06S120L and F12S100S-F12S100L) was about the same length, different axial strain values can be obtained from the displacements recorded based on LVDTs of different gauge lengths. This fact results in the lower ductility derived for the longer specimens (F06S120L and F12S100L) compared to the shorter ones (F06S120S and F12S100S). 


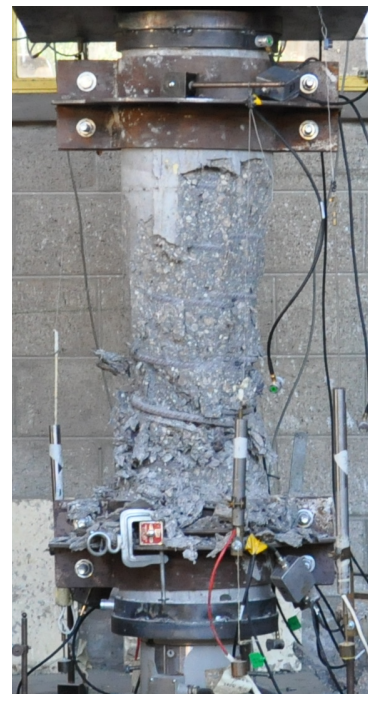

F12S100L

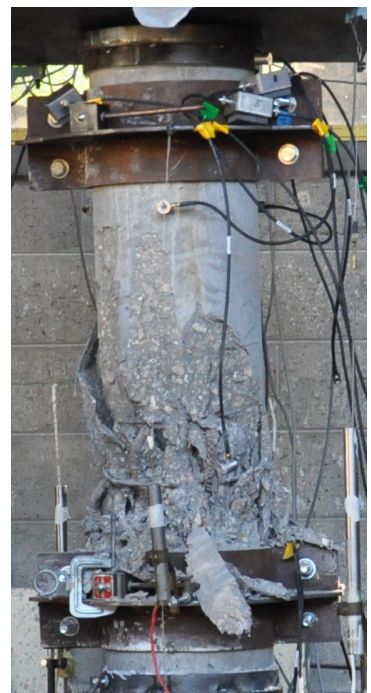

F06S120L

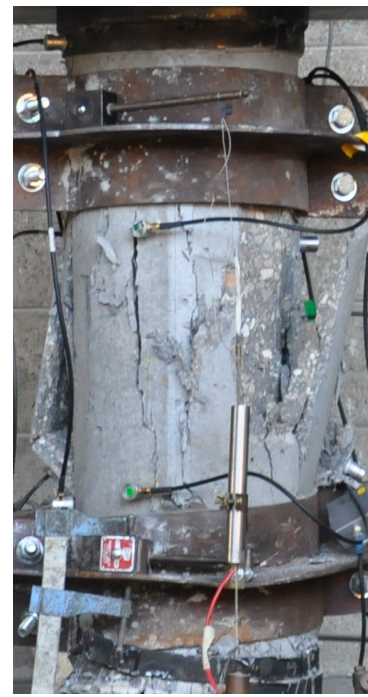

F12S100S

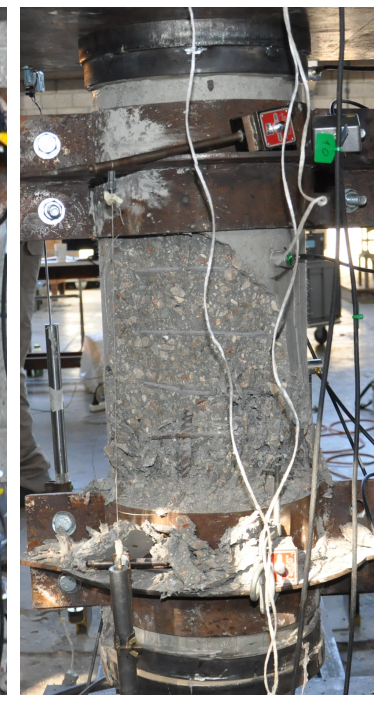

F06S120S

Figure 4. Appearance of specimens after testing.

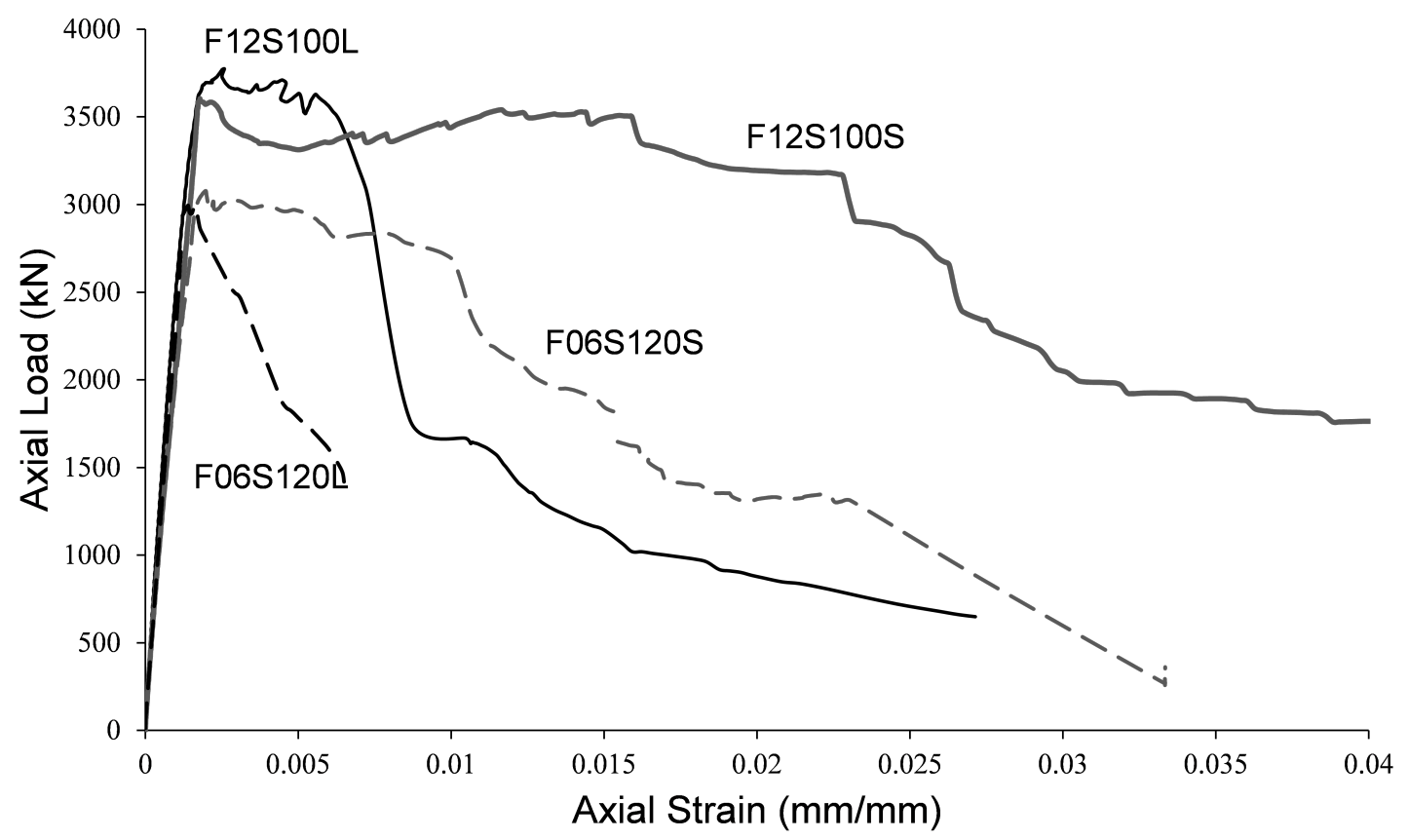

Figure 5. Axial load versus axial strain of the tested specimens

Analysis of damage development in specimens during loading was performed by calculation of distributions related to AE Absolute Energy $(E)$ and specifically, by calculation of AE cumulative absolute energy, $E_{n}$, and AE absolute energy rate, $E_{r}$, shown in Figures 6-8. AE absolute energy $(E)$ is an AE hit parameter derived by a squared sum of AE signal's voltage along the signal's duration divided on input impedance $(10 \mathrm{k} \Omega$ ) and presented in attoJoules (aJ) units. It is related phenomenologically to a portion of mechanical energy released in form of $\mathrm{AE}$ waves during a single fracture event in the RC element during its loading. Therefore, accumulation of fracture damage and its development can be instrumentally monitored by cumulative $\mathrm{AE}$ absolute energy, $E_{n}$. At the same time, the rate of damage accumulation and severity of fracture events, such as crack propagation in the material, change during increasing loading and so released $\mathrm{AE}$ absolute energy. Therefore, in order to track changes and trends in damage development, $\mathrm{AE}$ absolute energy rate, $E_{r}$, was calculated as a sum 
of $E$ of all $\mathrm{AE}$ events detected during time periods of 1 second. AE absolute energy rate $\left(E_{r}\right)$ allows detection of short duration time trends in acoustic emission data that consist of a large number of $\mathrm{AE}$ signals. It should be noted that, for specimen F06S120L, the AE system stopped to save AE data after 209 seconds due to technical issue. Therefore, the AE analysis of this specimen is based on the readings that were manually taken during testing (as presented in Table 3). Data presented in Figures 6-8 was recorded by sensor number 5 (see Figure 3), which was located in the middle of the specimen. Similar results were observed by all other sensors, which is reasonable taking into consideration the relatively small sensor spacing.

These figures show that $\mathrm{AE}$ distributions are categorized by three stages obtained in all specimens. These stages are defined by the following four reference points. (A) Initiation of AE activity, (B) peak $\mathrm{AE}$ absolute energy rate distribution (C) beginning of steady damage accumulation, and (D) the first AE macro event and initiation of macro-damage development. Reference points A, B, and D were obtained from $\mathrm{AE}$ absolute energy rate, while event $C$ was obtained from the cumulative $\mathrm{AE}$ absolute energy distribution at the moment, when a principle drop in the distribution's slope was detected. Thus, point $C$ was determined at the intersection of two tangential lines defined along the cumulative absolute energy curve (between points B and D). Moreover, point D was determined as the first $\mathrm{AE}$ event with discrete burst energy that is significantly higher than the preceding stage (which is characterized by concrete micro-cracking). The recorded loads at these events are given in Table 3 for all specimens. The change in the cumulative absolute AE energy, $E_{n}$, can indicate the damage level reached by the column [15]. It should be noted that this behavior, of three damage stages, was also reported by Mirmiran et al. [15] for NSC FRP-confined columns.

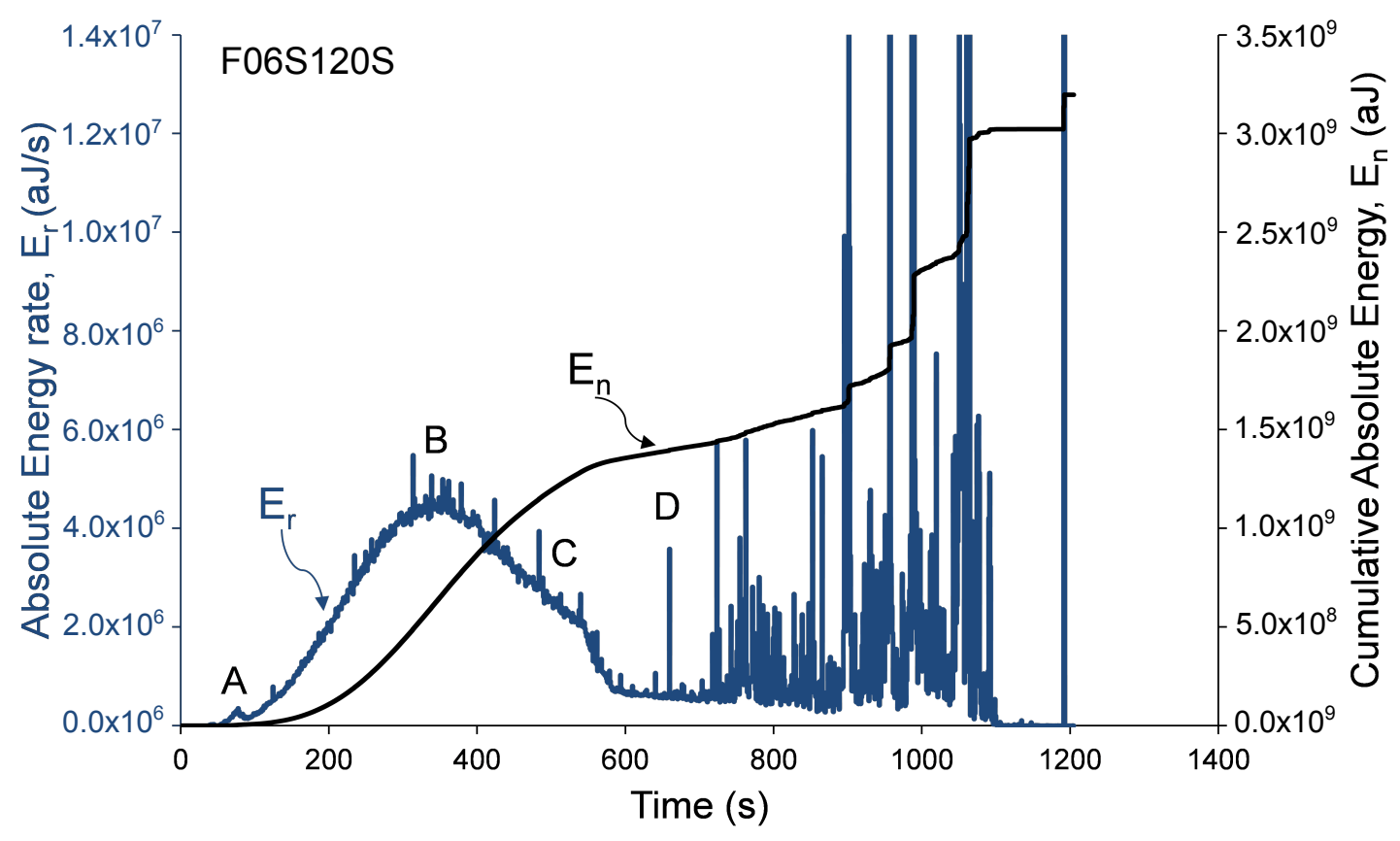

Figure 6. Absolute and cumulative absolute energy versus time—specimen F06S120S. 


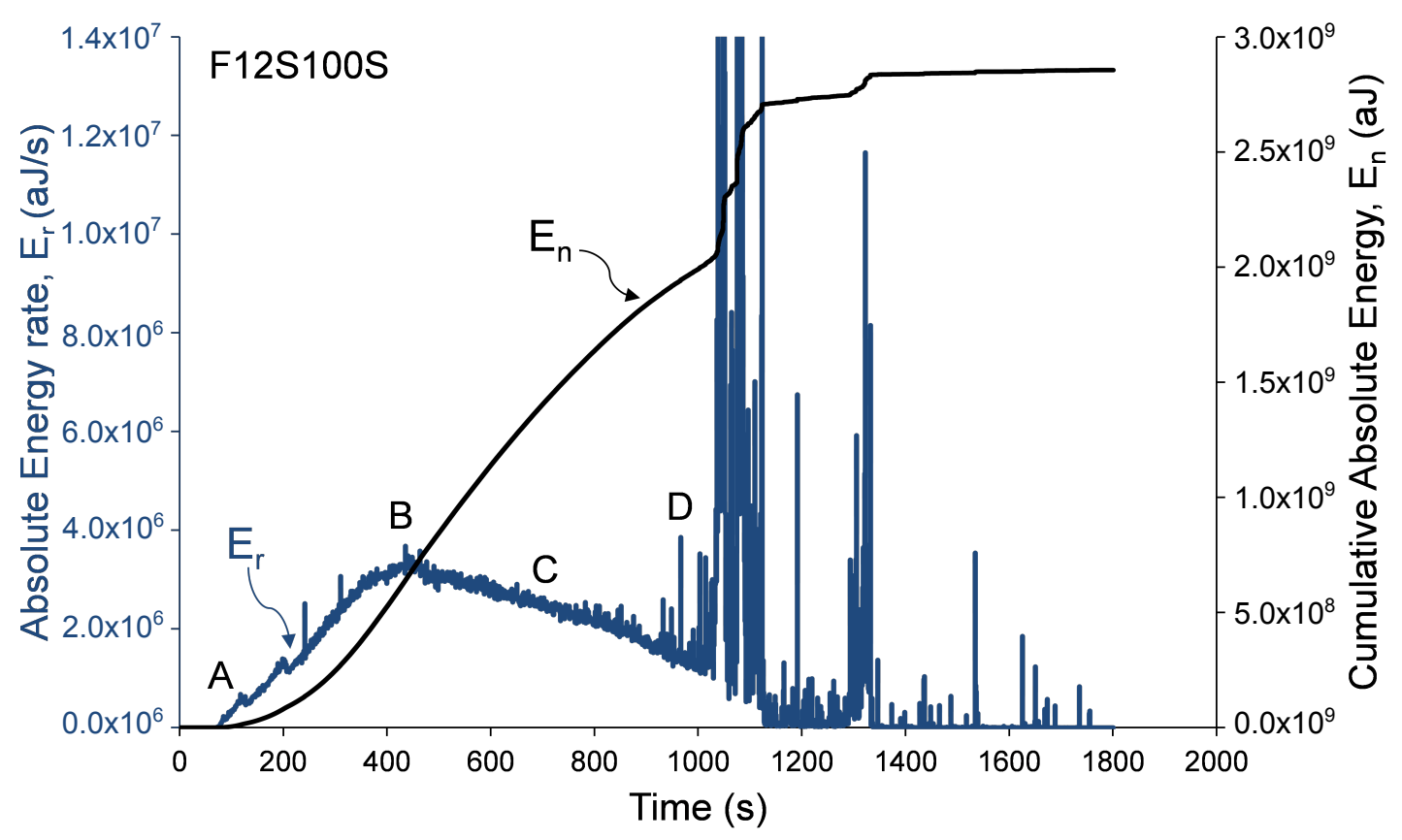

Figure 7. Absolute and cumulative absolute energy versus time—specimen F12S100S.

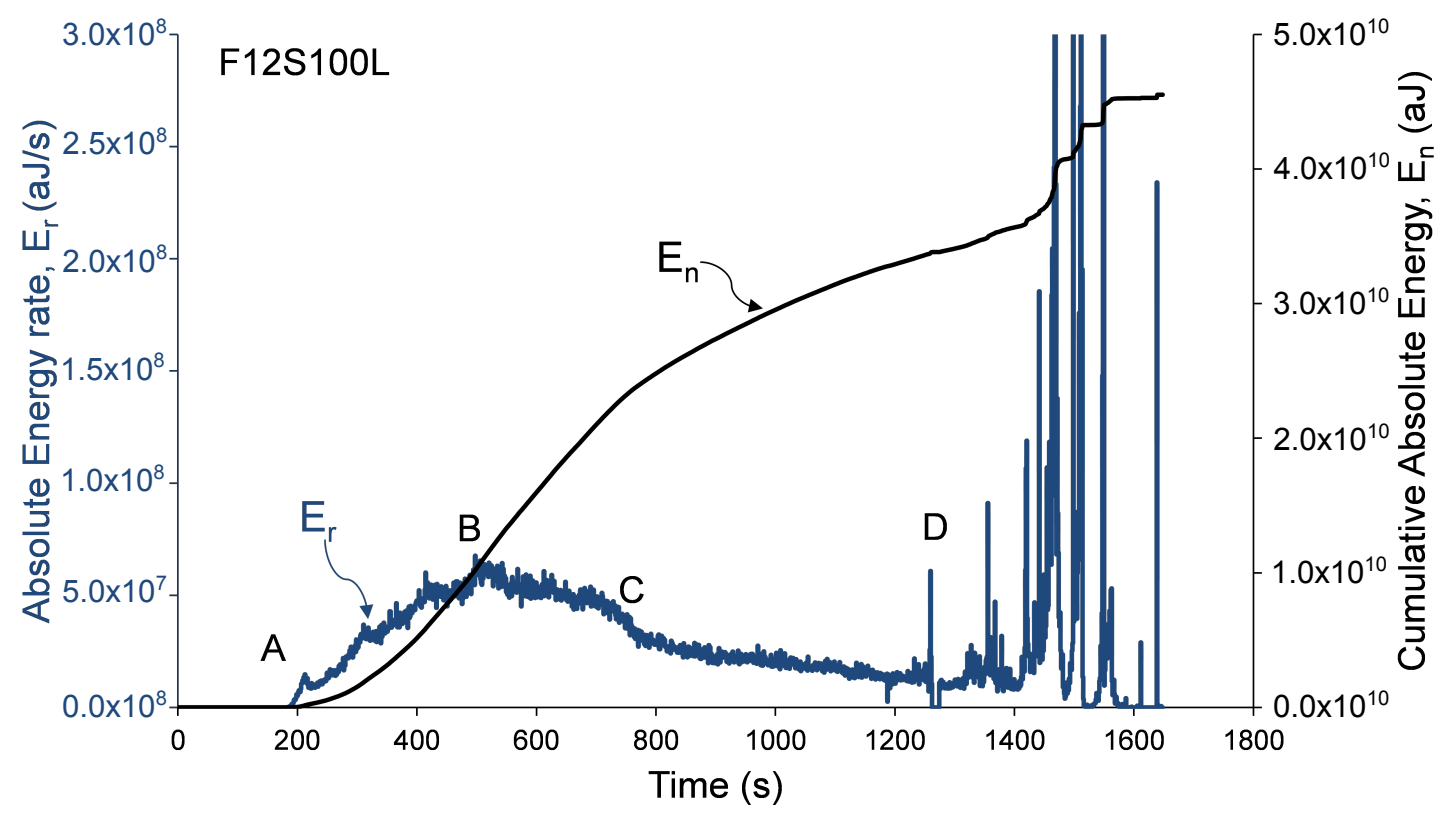

Figure 8. Absolute and cumulative absolute energy versus time—specimen F12S100L. 
Table 3. Test results.

\begin{tabular}{|c|c|c|c|c|c|c|c|c|c|c|c|c|}
\hline Specimen & $P_{\max }$ & $\epsilon_{c 1}$ & $\epsilon_{c p 50}$ & $A_{p 50}$ & $\begin{array}{c}P_{A}^{*} \\
\left(P_{A} / P_{\max }\right)\end{array}$ & $\begin{array}{c}P_{B}^{* *} \\
\left(P_{B} / P_{\max }\right)\end{array}$ & $\begin{array}{c}P_{C}^{+} \\
\left(P_{C} / P_{\text {max }}\right)\end{array}$ & $\begin{array}{c}P_{D}^{\ddagger} \\
\left(P_{D} / P_{\text {max }}\right)\end{array}$ & $\begin{array}{c}P_{0, E C 2} \\
\left(P_{0, E C 2} / P_{\max }\right)\end{array}$ & $\begin{array}{c}P_{0, A C I} \\
\left(P_{0, A C I} / P_{\text {max }}\right)\end{array}$ & $\begin{array}{c}P_{0, C S A} \\
\left(P_{0, C S A} / P_{\max }\right)\end{array}$ & $\begin{array}{c}P_{0, N Z S} \\
\left(P_{0, N Z S} / P_{\text {max }}\right)\end{array}$ \\
\hline & $(\mathrm{kN})$ & $(\mathrm{mm} / \mathrm{mm})$ & $(\mathrm{mm} / \mathrm{mm})$ & $(\mathrm{kN})$ & $(\mathrm{kN})$ & $(\mathrm{kN})$ & $(\mathrm{kN})$ & $(\mathrm{kN})$ & $(\mathrm{kN})$ & $(\mathrm{kN})$ & $(\mathrm{kN})$ & $(\mathrm{kN})$ \\
\hline F06S120S & 3079 & 0.0020 & 0.0168 & 36 & $\begin{array}{c}154 \\
(0.05)\end{array}$ & $\begin{array}{c}1249 \\
(0.41)\end{array}$ & $\begin{array}{c}2054 \\
(0.67)\end{array}$ & $\begin{array}{c}2636 \\
(0.86)\end{array}$ & $\begin{array}{c}3268 \\
(1.06)\end{array}$ & $\begin{array}{c}3872 \\
(1.26)\end{array}$ & $\begin{array}{c}3352 \\
(1.09)\end{array}$ & $\begin{array}{c}3463 \\
(1.12)\end{array}$ \\
\hline F06S120L & 2994 & 0.0014 & 0.0065 & 13 & $\begin{array}{c}89 \\
(0.03)\end{array}$ & $\begin{array}{c}1549 \\
(0.52)\end{array}$ & $\begin{array}{c}2074 \\
(0.69)\end{array}$ & $\begin{array}{c}2783 \\
(0.93)\end{array}$ & $\begin{array}{c}3026 \\
(1.01)\end{array}$ & $\begin{array}{c}3352 \\
(1.12)\end{array}$ & $\begin{array}{c}2976 \\
(0.99)\end{array}$ & $\begin{array}{c}3114 \\
(1.04)\end{array}$ \\
\hline F12S100S & 3604 & 0.0018 & 0.0384 & 109 & $\begin{array}{c}87 \\
(0.02)\end{array}$ & $\begin{array}{c}1057 \\
(0.29)\end{array}$ & $\begin{array}{c}2100 \\
(0.58)\end{array}$ & $\begin{array}{c}3206 \\
(0.89)\end{array}$ & $\begin{array}{l}3105 \\
(0.86)\end{array}$ & $\begin{array}{l}3507 \\
(0.97)\end{array}$ & $\begin{array}{l}3091 \\
(0.86)\end{array}$ & $\begin{array}{l}3202 \\
(0.89)\end{array}$ \\
\hline F12S100L & 3774 & 0.0026 & 0.0087 & 30 & $\begin{array}{c}20 \\
(0.01)\end{array}$ & $\begin{array}{c}1014 \\
(0.27)\end{array}$ & $\begin{array}{c}1889 \\
(0.50)\end{array}$ & $\begin{array}{c}3448 \\
(0.91)\end{array}$ & $\begin{array}{c}3292 \\
(0.87)\end{array}$ & $\begin{array}{c}3933 \\
(1.04)\end{array}$ & $\begin{array}{c}3395 \\
(0.90)\end{array}$ & $\begin{array}{c}3517 \\
(0.93)\end{array}$ \\
\hline
\end{tabular}

${ }^{*}$ Load at initiation of significant AE activity. ${ }^{* *}$ Load at peak AE energy distribution. ${ }^{\dagger}$ Load at beginning of steady damage accumulation. ${ }^{\ddagger}$ Load at the first $\mathrm{AE}$ macro event. 


\subsection{Acoustic Emission and Compressive Behavior}

The leading RC design standards [23-25,27] give different estimations for the nominal axial load strength of HSC columns [1]. The general expression of the nominal axial load strength is $P_{0}=\alpha_{1}\left(A_{g}-A_{s \ell}\right) f_{c}^{\prime}+A_{s \ell} f_{y}$, where $A_{g}$ is the column's gross cross-sectional area, $A_{s \ell}$ is the longitudinal steel reinforcement cross-sectional area, $f_{y}$ is longitudinal steel reinforcement yield strength, and $\alpha_{1}$ is a parameter, which for the majority of the standards decreases as the concrete strength increases (except in the ACI [27] where $\alpha_{1}$ is constant and equal to 0.85 ). The $\alpha_{1}$ parameter is given as $[1,23-25,27]$

$$
\begin{aligned}
& \alpha_{1, A C I}=0.85 \\
& \alpha_{1, C S A}=0.85-0.0015 f_{c}^{\prime} \geq 0.67 \quad \text { for } 20 \mathrm{MPa}<f_{c}^{\prime} \leq 80 \mathrm{MPa} \\
& \alpha_{1, N Z S}= \begin{cases}0.85 & \text { for } f_{c}^{\prime} \leq 55 \mathrm{MPa} \\
0.85-0.004\left(f_{c}^{\prime}-55\right) \geq 0.75 & \text { for } 55 \mathrm{MPa}<f_{c}^{\prime} \leq 70 \mathrm{MPa}\end{cases} \\
& \alpha_{1, E C 2}= \begin{cases}\alpha_{c c} & \text { for } f_{c}^{\prime} \leq 50 \mathrm{MPa} \\
\alpha_{c c}\left[1.0-\left(f_{c}^{\prime}-50\right) / 200\right] & \text { for } 50 \mathrm{MPa}<f_{c}^{\prime} \leq 90 \mathrm{MPa}\end{cases}
\end{aligned}
$$

where $\alpha_{c c}$, which has a range of 0.8 to 1.0 [23], is a coefficient that considers the long-term influence on the axial strength and of negative effects resulting from the way the load is applied [23]. One of the main reasons for decreasing $\alpha_{1}$ as the concrete strength increases is the premature failure of the concrete cover. To evaluate the AE records with the compressive behavior of the HSC specimens, the axial load and the $\mathrm{AE}$ absolute energy rate are presented with relation to the axial strain in Figures 9-12. The figures also show the ranges of the following axial strengths derived from the different standards [23-25,27]. The nominal axial load strength, $P_{0}$; the design axial compressive strength, $P_{n}$, which is based on $P_{0}$ with material safety factors; and serviceability axial compressive strength $P_{\text {ser }}$, which is estimated as $P_{n} / 1.4$, where the factor 1.4 is the equivalent safety load factor (taking into account that the dead and live loads are the dominant loads). Moreover, the loads that were reached at certain events recorded by $\mathrm{AE}$ sensors and were defined in Table 3 are also marked in Figures $9-12\left(P_{B}=\right.$ load at peak AE energy rate distribution, $P_{C}=$ load at beginning of steady damage accumulation, and $P_{D}=$ load at the first AE macro event).

It is interesting to note (Figures 9-12) that the levels of loads reached at the peak AE absolute energy rate distribution $\left(P_{B}\right)$ are similar to the levels of the assumed serviceability axial compressive strengths, $P_{s e r}$, of the tested specimens. The levels of loads reached at the beginning of steady damage accumulation $\left(P_{C}\right)$ are similar to the levels of the design axial compressive strengths, $P_{n}$, of the tested specimens. Moreover, and most interesting, the levels of loads reached at the first AE macro event $\left(P_{D}\right)$ are similar to the lower range levels of the nominal axial compressive strengths, $P_{0}$, of the tested specimens. It is believed that the first $\mathrm{AE}$ macro event indicates the beginning of the premature failure of the concrete cover. Thus, from these results, it can be concluded that the lower range levels (obtained by the standards [23-25]) are on the safer side for determining the nominal axial compressive strength of HSC columns. This result is consistent with studies reported elsewhere [28-32].

$\mathrm{AE}$ data was also analyzed to study 3D source location of the AE events detected during loading tests. Location calculations were performed using Vallen AE software with 3D solid algorithm [33] and using the nine AE sensors installed along the column specimens. To investigate the distribution of $\mathrm{AE}$ events across a cross section of specimen, a radial distance for every AE event was calculated. Figures 13-16 show the AE source events along the radial distance of the column's cross section (taking into account the events at the entire column's height) for all specimens. The figures show that the majority of $\mathrm{AE}$ events were located at the the concrete cover and especially those associated with the macro cracking at load levels around $P_{D}$ (see Figures $13 b, 15 b$, and 16b). This result conform to the phenomenon mentioned above, i.e., the premature failure of the concrete cover in HSC columns. It should be also noted that from the presented results there is a slight difference in the overall 
$\mathrm{AE}$ activity before the onset of the macro cracking events for columns with different confinement reinforcement or height.

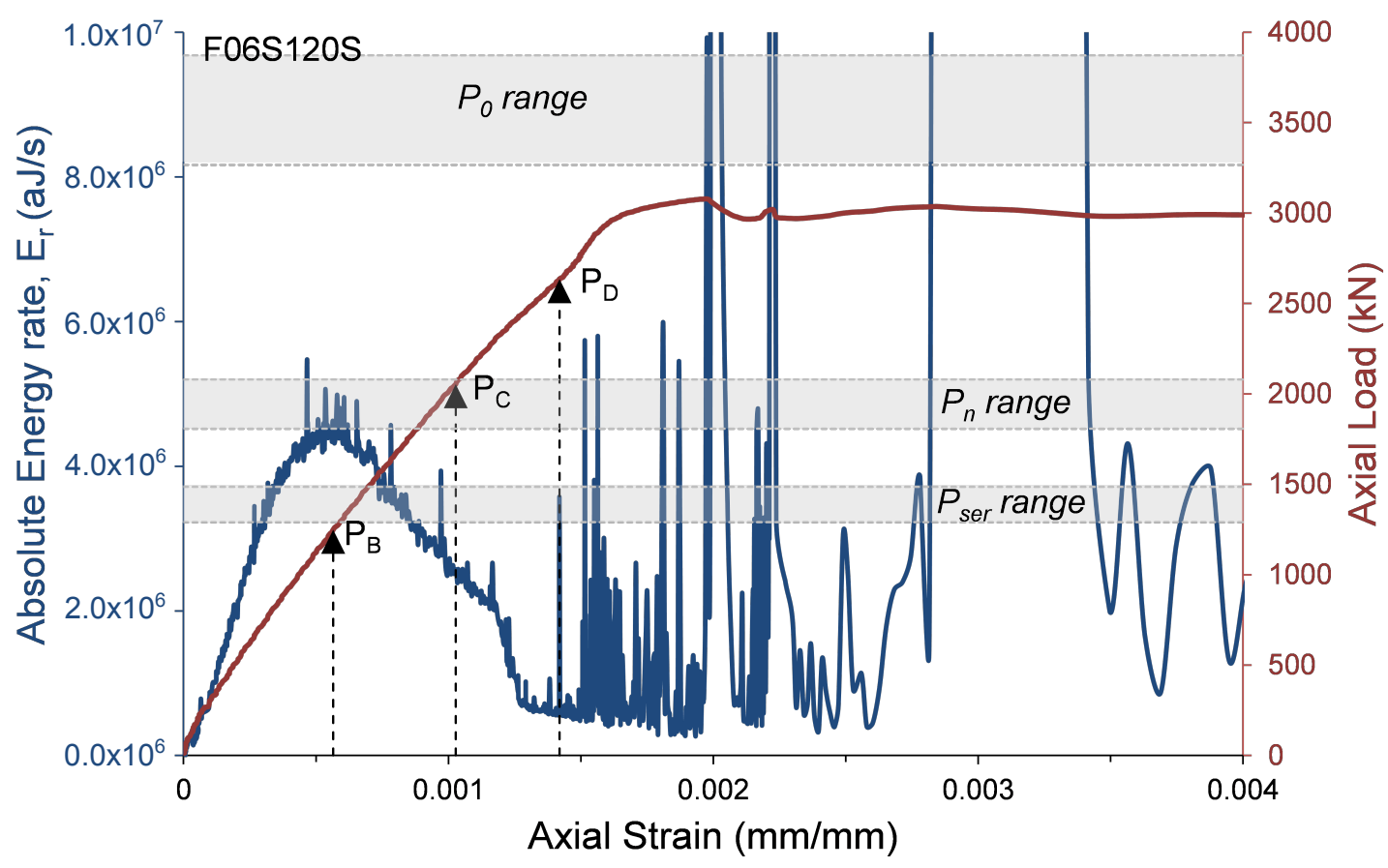

Figure 9. Absolute energy and axial load versus axial strain—specimen F06S120S.

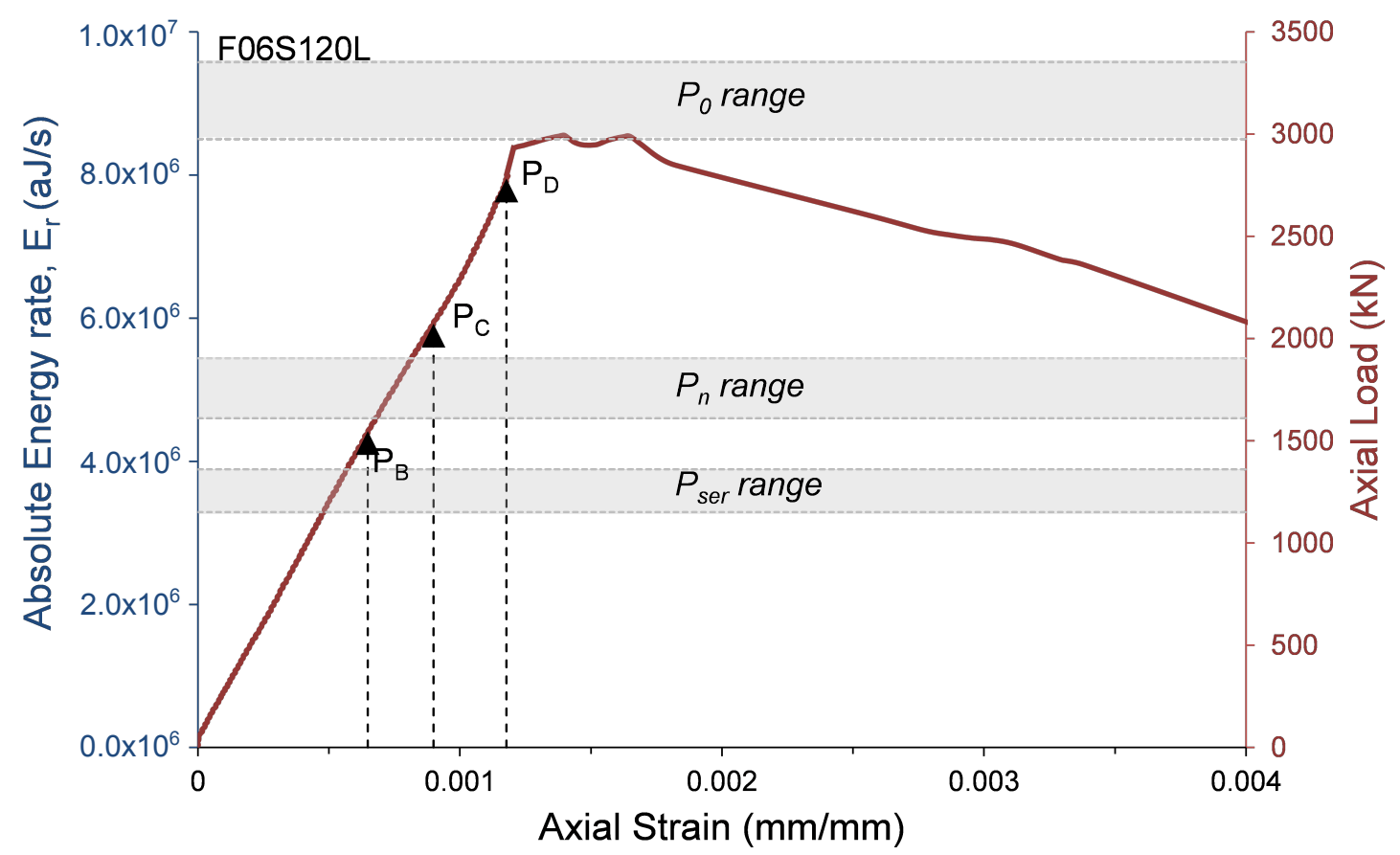

Figure 10. Absolute energy and axial load versus axial strain—specimen F06S120L. 


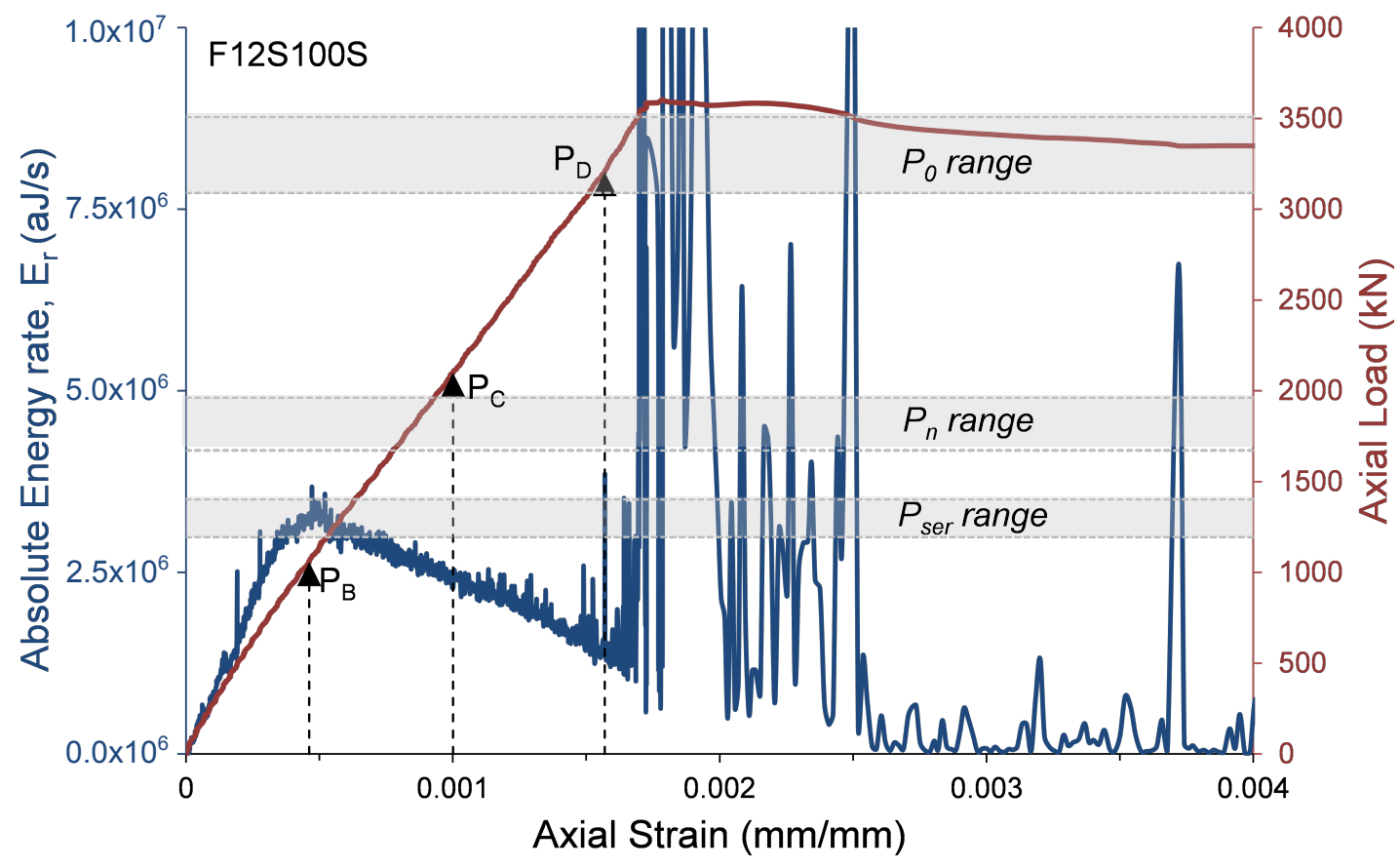

Figure 11. Absolute energy and axial load versus axial strain—specimen F12S100S.

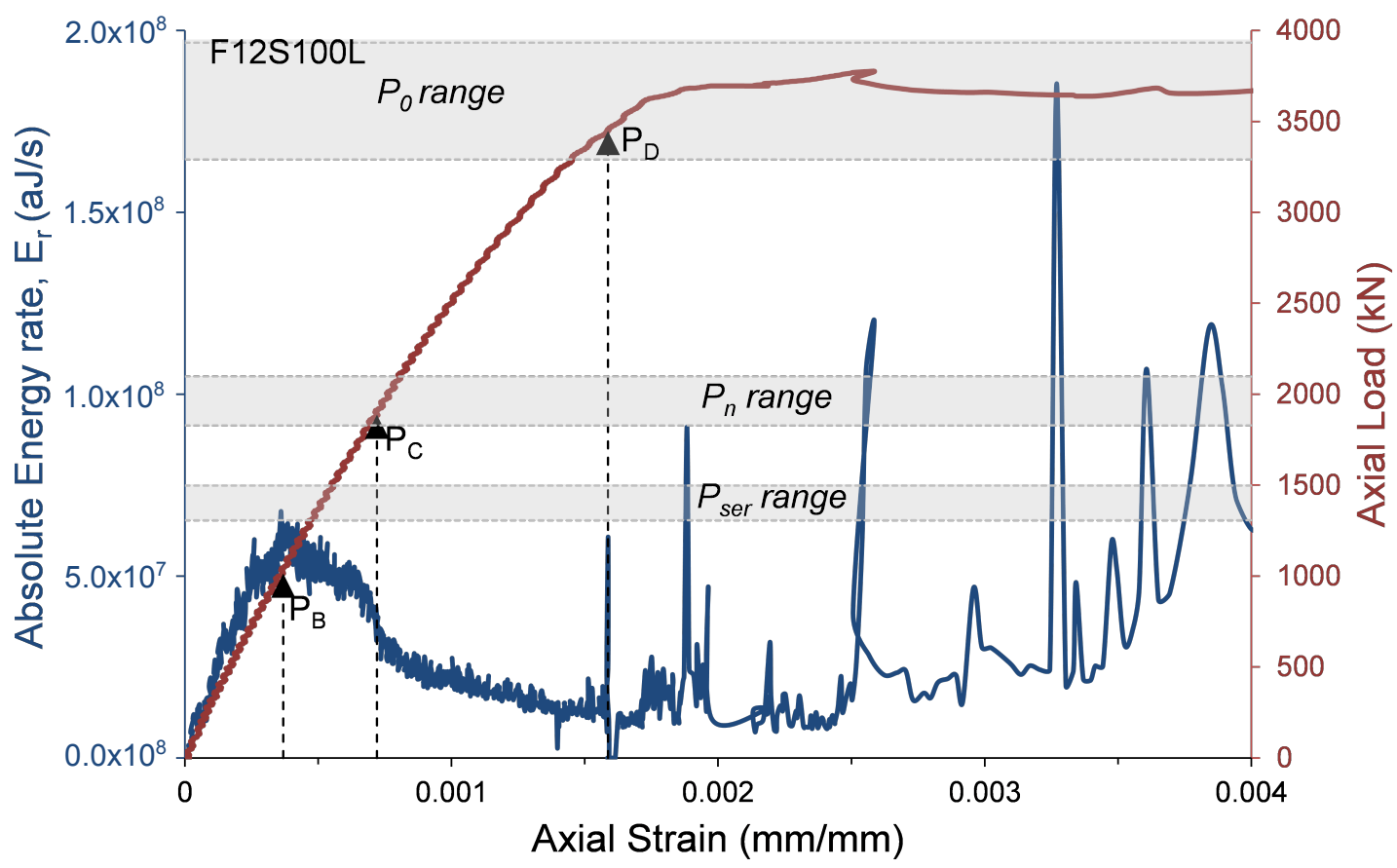

Figure 12. Absolute energy and axial load versus axial strain—specimen F12S100L. 

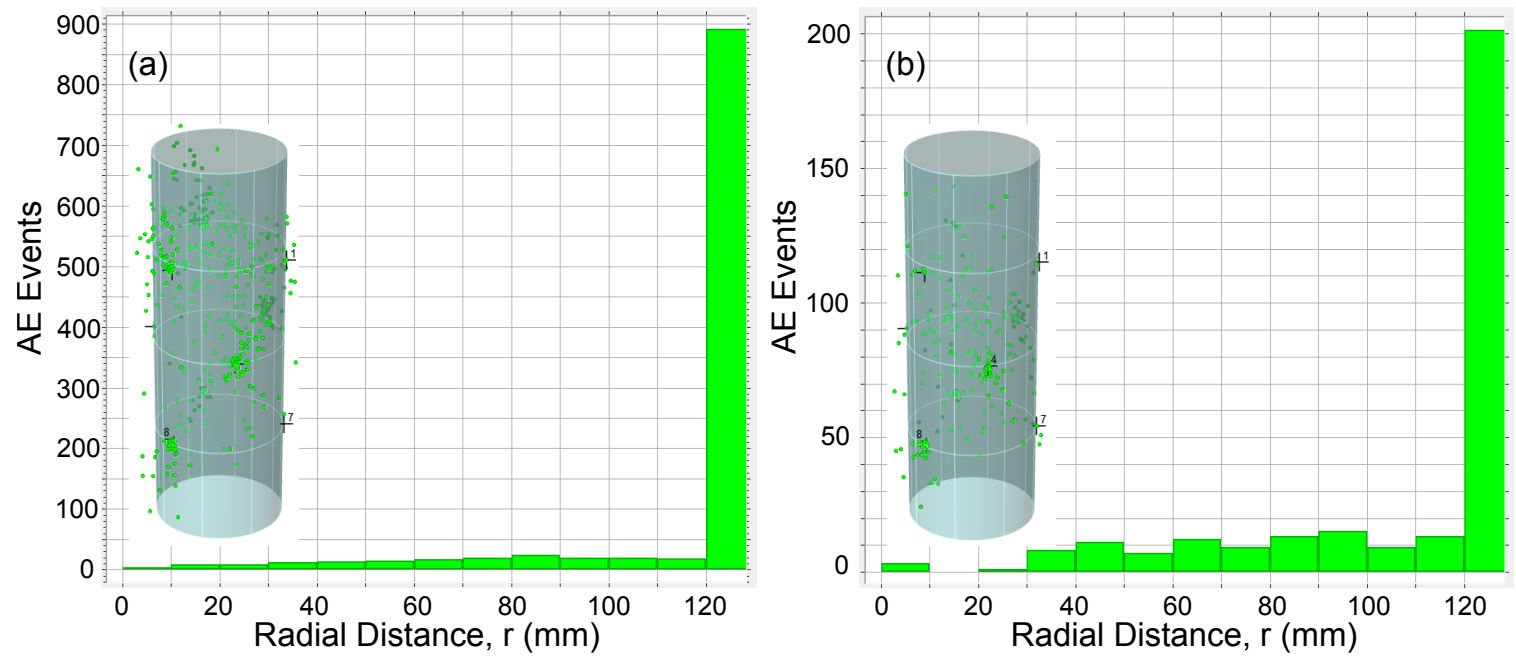

Figure 13. AE events along specimen F06S120S cross section for (a) $t<500 \mathrm{~s}$ and (b) $t \geq 500 \mathrm{~s}$.

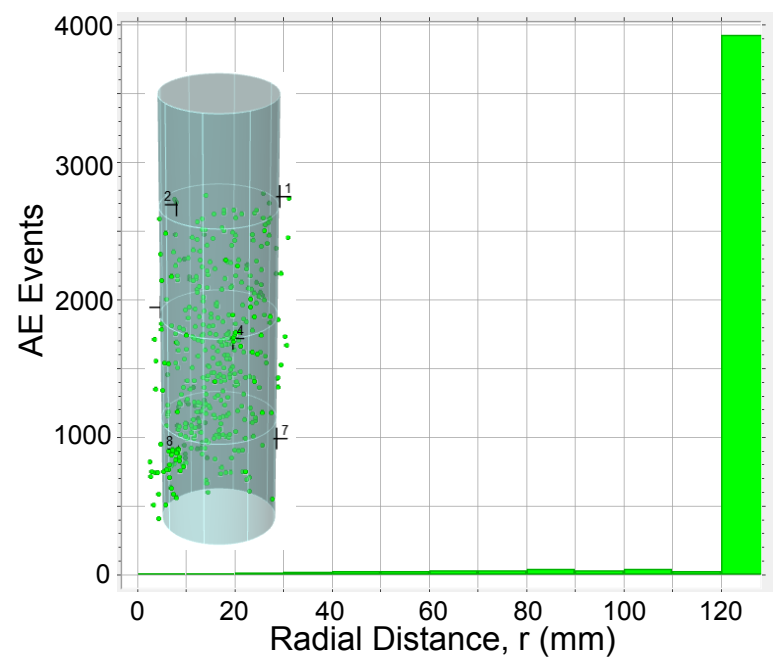

Figure 14. AE events along specimen F06S120L cross section for $t<180 \mathrm{~s}$.
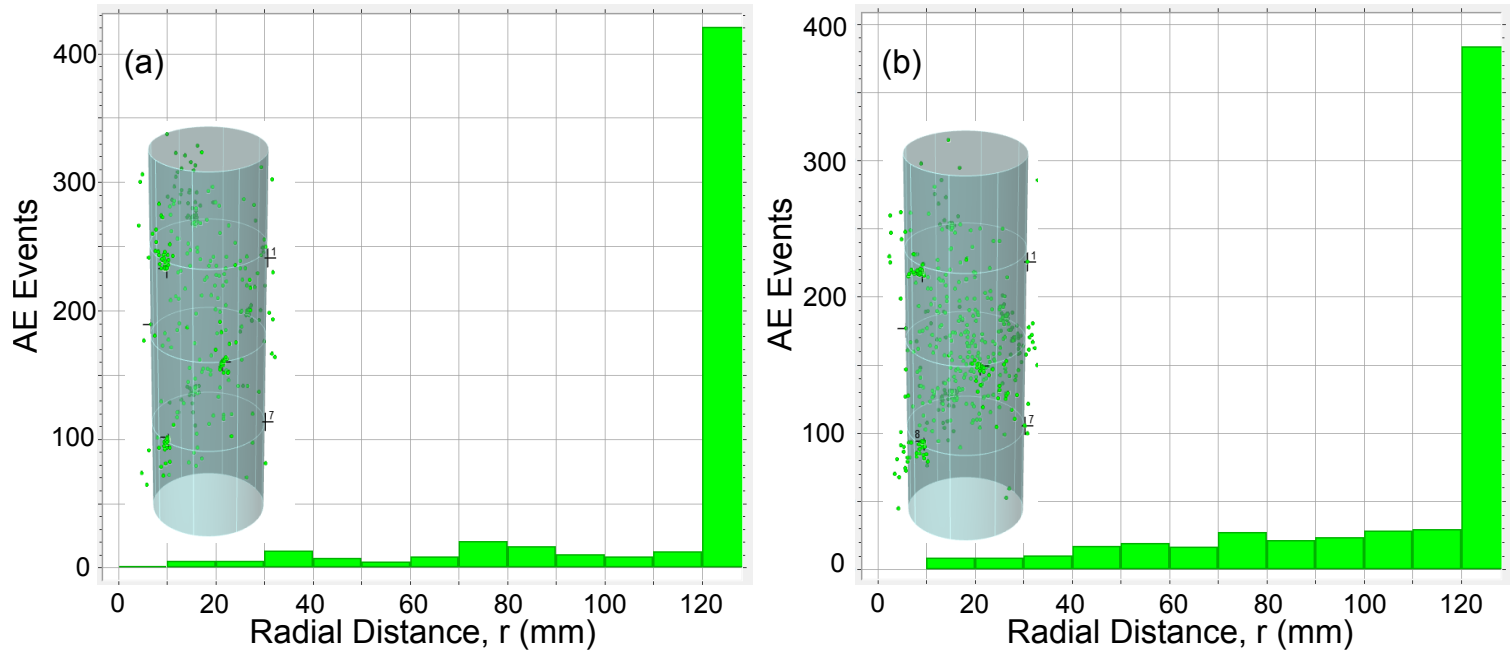

Figure 15. AE events along specimen F12S100L cross section for (a) $t<722 \mathrm{~s}$ and (b) $t \geq 722 \mathrm{~s}$. 

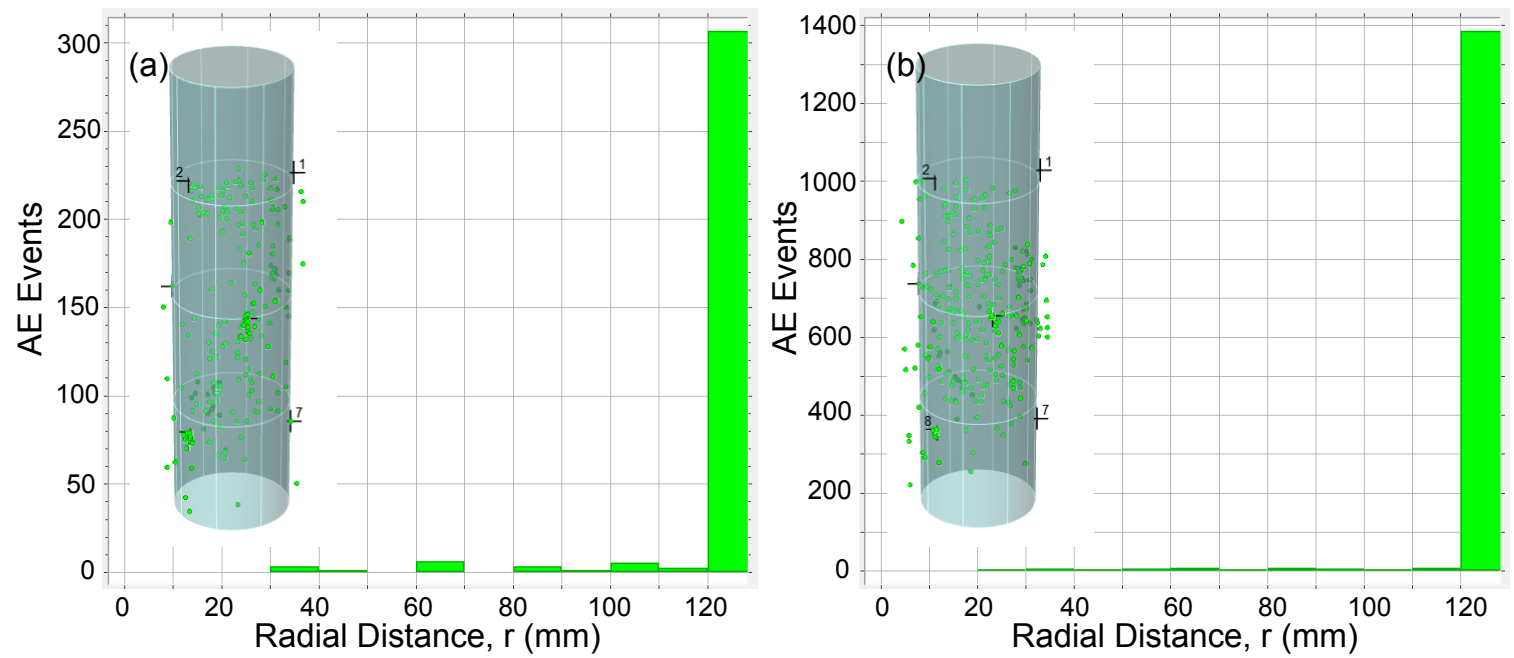

Figure 16. AE events along specimen F12S100L cross section for (a) $t<750 \mathrm{~s}$ and (b) $750 \leq t \leq 950 \mathrm{~s}$.

\section{Conclusions}

This paper presents a study on the acoustic emission (AE) monitoring of high-strength concrete columns subjected to compressive axial loading. The study consists of four large-scale reinforced high-strength concrete columns with different confinement reinforcement amounts and heights. The results of the study show the following.

- The AE distributions in the columns are categorized by three stages defined by the initiation of $\mathrm{AE}$ activity, the peak $\mathrm{AE}$ absolute energy rate distribution, the beginning of steady damage accumulation, and the first $\mathrm{AE}$ macro event and initiation of macro-damage development.

- The levels of loads reached at the peak AE energy distribution are similar to the levels of the assumed serviceability axial compressive strengths of the tested specimens.

- The levels of loads reached at the beginning of steady damage accumulation are similar to the levels of the design axial compressive strengths of the tested specimens.

- The levels of loads reached at the first AE macro event are similar to the lower range levels of the nominal axial compressive strengths of the tested specimens.

- The majority of AE events are located at the concrete cover and especially those associated with the macro-cracking.

It is believed that the first $\mathrm{AE}$ macro event indicates the beginning of the premature failure of the concrete cover. Thus, this phenomenon should be taken into account in the determination of the nominal axial load compressive strength as prescribed in part of the leading standards. Moreover, based on the results of this study, AE monitoring can provide correlation between the damage and load levels (e.g., design axial compressive strength) attained by reinforced high-strength concrete columns subjected to compressive axial loading and the AE results. Future studies can include additional loading schedules like loading/unloading to provide more information regarding stages of damage/cracks development in the columns and specifically regarding the load levels at which irreversible damage is initiated.

Author Contributions: Methodology, R.E., B.M. and K.K.; Formal analysis, R.E. and B.M.; Investigation, R.E., B.M. and K.K.; Conceptualization of paper, R.E.; Writing of paper, R.E.; All authors have read and agreed to the published version of the manuscript.

Funding: This research received no external funding.

Acknowledgments: The authors would like to thank Ami Dahan from Israbeton Concrete-part of Ashtrom Industries, for his collaboration and important role in this research study. The technical assistance of Yakov Vitman, Elhanan Izhak, and Eddi Gershengoren from the National Building Research Institute at the Technion-Israel Institute of Technology, is gratefully acknowledged. 
Conflicts of Interest: The authors declare no conflict of interest.

\section{Abbreviations}

The following abbreviations are used in this manuscript.

$\begin{array}{ll}\text { AE } & \text { Acoustic Emission } \\ \text { TSR } & \text { Transverse steel reinforcement } \\ \text { NSC } & \text { Normal-strength concrete } \\ \text { HSC } & \text { High-strength concrete } \\ \text { RC } & \text { Reinforced-concrete }\end{array}$

\section{References}

1. Eid, R.; Kovler, K.; David, I.; Khoury, W.; Miller, S. Behavior and design of high-strength circular reinforced concrete columns subjected to axial compression. Eng. Struct. 2018, 173, 472-480. [CrossRef]

2. Paultre, P.; Khayat, K.H.; Langlois, Y.; Trudel, A.; Cusson, D. Structural performance of some special concretes. In Proceedings of the 4th International Sumposium on Utilization of High-Strength/High-performance Concrete, Paris, France, 29-31 May 1996; pp. 787-796.

3. Foster, S.J.; Liu, J.; Sheikh, S.A. Cover spalling in HSC columns loaded in concentric compression. ASCE J. Struct. Eng. 1998, 124, 1431-1437. [CrossRef]

4. Khaliq, W.; Kodur, V. Effectiveness of polypropylene and steel fibers in enhancing fire resistance of high-strength concrete columns. ASCE J. Struct. Eng. 2018, 144, 04017224. [CrossRef]

5. Hager, I.; Mróz, K. Role of polypropylene fibres in concrete spalling risk mitigation in fire and test methods of fibres effectiveness evaluation. Materials 2019, 12, 3869. [CrossRef] [PubMed]

6. Bangi, M.R.; Horiguchi, T. Effect of fibre type and geometry on maximum pore pressures in fibre-reinforced high strength concrete at elevated temperatures. Cem. Concr. Res. 2012, 42, 459-466. [CrossRef]

7. Zhu, Y.K.; Tian, G.Y.; Lu, R.S.; Zhang, H. A review of optical NDT technologies. Sensors 2011, 11, 7773-7798. [CrossRef]

8. Maj, M.; Ubysz, A.; Hammadeh, H.; Askifi, F. Non-destructive testing of technical conditions of RC industrial tall chimneys subjected to high temperature. Materials 2019, 12, 2027. [CrossRef]

9. Schabowicz, K. Non-destructive testing of materials in civil engineering. Materials 2019, 12, 3237. [CrossRef]

10. Kobaka, J.; Katzer, J.; Ponikiewski, T. A combined electromagnetic induction and radar-based test for quality control of steel fibre reinforced concrete. Materials 2019, 12, 3507. [CrossRef] [PubMed]

11. Ahn, E.; Kim, H.; Sim, S.H.; Shin, S.W.; Shin, M. Principles and applications of ultrasonic-based nondestructive methods for self-healing in cementitious materials. Materials 2017, 10, 278. [CrossRef]

12. Climent, M.A.; Miró, M.; Carbajo, J.; Poveda, P.; De Vera, G.; Ramis, J. Use of non-linear ultrasonic techniques to detect cracks due to steel corrosion in reinforced concrete structures. Materials 2019, 12, 813. [CrossRef] [PubMed]

13. Xiao, M.; Ju, F.; Ning, P.; Li, K. Mechanical and acoustic emission behavior of gangue concrete under uniaxial compression. Materials 2019, 12, 3318. [CrossRef] [PubMed]

14. Abarkane, C.; Rescalvo, F.J.; Donaire-Ávila, J.; Galé-Lamuela, D.; Benavent-Climent, A.; Molina, A.G. Temporal acoustic emission index for damage monitoring of RC structures subjected to bidirectional seismic loadings. Materials 2019, 12, 2804. [CrossRef]

15. Mirmiran, A.; Shahawy, M.; El Echary, H. Acoustic emission monitoring of hybrid FRP-concrete columns. ASCE J. Eng. Mech. 1999, 125, 899-905. [CrossRef]

16. Ma, G.; Li, H. Acoustic emission monitoring and damage assessment of FRP-strengthened reinforced concrete columns under cyclic loading. Constr. Build. Mater. 2017, 144, 86-98. [CrossRef]

17. Puri, S.; Weiss, J. Assessment of localized damage in concrete under compression using acoustic emission. ASCE J. Mater. Civ. Eng. 2006, 18, 325-333. [CrossRef]

18. Benavent-Climent, A.; Castro, E.; Gallego, A. AE monitoring for damage assessment of RC exterior beam-column subassemblages subjected to cyclic loading. Struct. Health Monit. 2009, 8, 175-189. [CrossRef]

19. Benavent-Climent, A.; Gallego, A.; Vico, J.M. An acoustic emission energy index for damage evaluation of reinforced concrete slabs under seismic loads. Struct. Health Monit. 2011, 11, 69-81. [CrossRef] 
20. Du, F.; Li, D.; Shan, B.; Wang, Y. Failure behavior monitoring and evaluation of steel-confined reinforced concrete columns by acoustic emission under quasi-static loading. Latin Am. J. Solids Struct. 2018, 15, 1-18. [CrossRef]

21. Li, D.; Chen, Z.; Feng, Q.; Wang, Y. Damage analysis of CFRP-confined circular concrete-filled steel tubular columns by acoustic emission techniques. Smart Mater. Struct. 2015, 24, 085017. [CrossRef]

22. Aldahdooh, M.A.A.; Bunnori, N.M.; M., J.M.A. Damage evaluation of reinforced concrete beams with varying thickness using the acoustic emission technique. Constr. Build. Mater. 2013, 44, 812-821. [CrossRef]

23. European Standard 1992-1-1. Eurocode 2: Design of Concrete Structures. Part 1-1: General Rules and Rules for Buildings; European Committee for Standardization: Brussels, Belgium, 2004.

24. Canadian Standard Association (CSA) A23.3. Design of Concrete Structures; CSA Group: Toronto, ON, Canada, 2014.

25. Standards New Zealand (NZS) 3101. Concrete Structures Standard, Part 1-The Design of Concrete Structures; Standards New Zealand: Wellington, New Zealand, 2006.

26. Eid, R.; Cohen, A.; Guma, R.; Ifrach, E.; Levi, N.; Zvi, A. High-strength concrete circular columns with TRC-TSR dual internal confinement. Buildings 2019, 9, 218. [CrossRef]

27. American Concrete Institute ACI 318. Building Code Requirements for Structural Concrete; ACI 318: Farmington Hills, MI, USA, 2019.

28. Razvi, S.R.; Saatcioglu, M. Strength and deformability of confined high-strength concrete columns. ACI Struct. J. 1994, 91, 678-687.

29. Azizinamini, A.; Kuska, S.S.B.; Brungardt, P.; Hatfield, E. Seismic Behavior of Square High-Strength Concrete Columns. ACI Struct. J. 1994, 91, 336-345.

30. Ozbakkaloglu, T.; Saatcioglu, M. Rectangular stress block for high-strength concrete. ACI Struct. J. 2004, 101, 475-483.

31. Bae, S.; Bayrak, O. Examination of stress block Parameters for high-strength concrete in the context of ACI 318 Code. In Proceedings of the Reinforced Concrete Columns with High Strength Concrete and Steel Reinforcement, SP-293, Farmington Hills, MI, USA, 9 January 2013; pp. 59-77.

32. American Concrete Institute ACI 441.1R-18. Report on Equivalent Rectangular Concrete Stress Block and Transverse Reinforcement for High-Strength Concrete Columns; American Concrete Institute: Farmington Hills, MI, USA, 2018.

33. Vallen Systeme GmbH. Vallen AE-Suite Software; Version R2019.0926.2; Vallen Systeme GmbH: Icking, Germany, 2019.

(C) 2020 by the authors. Licensee MDPI, Basel, Switzerland. This article is an open access article distributed under the terms and conditions of the Creative Commons Attribution (CC BY) license (http://creativecommons.org/licenses/by/4.0/). 